\title{
The Impact of Environmental Factors on the International Harmonization Process of Accounting on SMEs: Evidence in Vietnam*
}

\author{
Dung Duc NGUYEN ${ }^{1}$
}

Received: August 01, 2020 Revised: September 06, 2020 Accepted: September 10, 2020

\begin{abstract}
The study examines the effect of environmental factors on the international harmonization process of accounting on small and medium enterprises in Vietnam. These factors include legal environment, business environment, and cultural environment. The data is collected by a survey of 100 accountants and 100 auditors on the factors that affects the international harmonization process of accounting. The T-Tests indicate differences between the answers of the accountants and auditors. First, for the accountants, legal environment has the biggest effect on the harmonization process of accounting; while on the auditors, business environment has the biggest influence. Second, while the accountants consider costs higher than benefits in the harmonization process of accounting, the auditors assume that benefits are superior to costs that businesses spend. Third, both the accountants and the auditors indicate that the harmonization process of accounting should not be applied for all small and medium enterprises. From the study results, the author has given a different evaluation method that Vietnam should implement for international harmonization with the required adjustments as per the suitability with the status of businesses in Vietnam. The process of harmonization in accounting practices should not be indiscriminately applied to all the small and medium enterprises either.
\end{abstract}

Keywords: IFRS, Cultural Environment, Legal Environment, Economic Environment, Small and Medium Enterprises

JEL Classification Code: D81, E60, G11, G18, G41

\section{Introduction}

Vietnamese small and medium enterprises occupy approximately $80 \%$ of total businesses operating in the whole country, but they are small-scale ones with low development stage, especially their accounting system. Vietnamese small and medium enterprises are gaining in strength and their participation in international operations is increasing. To sustain their increasing growth, they need to attract domestic and foreign investments for development, thus, the demand

\footnotetext{
*Acknowledgements:

This research is funded by the National Economics University (NEU), Hanoi, Vietnam. The author thank anonymous referees for their contributions and the NEU for funding this research.

${ }^{1}$ First Author and Corresponding Author. Lecturer, School of Accounting and Auditing, National Economics University, Vietnam [Postal Address: 207 Giai Phong Road, Dong Tam Ward, Hai Ba Trung District, Hanoi, 113068, Vietnam]

Email: dungnd2141@gmail.com

(c) Copyright: The Author(s)

This is an Open Access article distributed under the terms of the Creative Commons Attribution Non-Commercial License (https://creativecommons.org/licenses/by-nc/4.0/) which permits unrestricted non-commercial use, distribution, and reproduction in any medium, provided the original work is properly cited.
}

for transparent financial information becomes imperative. Therefore, Vietnam, like other countries, has the increasing pressure for the international harmonization of financial statement standards of small and medium enterprises. While dealing with the issue of the harmonization of accounting of small and medium enterprises in the world, IASB indicates that it is necessary to build separate international financial statement standards for small and medium enterprises because their financial reports need to be compared with the global standards as these businesses need to move towards the international harmonization process. The application of IFRS is a reliable and convenient way for the harmonization process of accounting, but at the same time this is a very complicated solution that lays a significant burden on small and medium enterprises. There have been many surveys which conclude that International Financial Reporting Standards (IFRS) should not be generally applied for small and medium businesses.

In February 2007, IASB issued a draft of IFRS for SMEs together with the document "IFRS for SMEs Basis for Conclusions". The IFRS for SMEs draft has been built on the basis of events that regularly appear in SMEs with a capacity up to 50 employees. When compared to IFRS, the different 
regulations, rules, and definitions of this draft are considered to not only meet with the demands of small and medium enterprises but also to balance costs and benefits when applying it. Vietnam is an interesting example of the study on IFRS reception because it is an emerging and changing economy. When comparing Vietnam to other developing countries, the economic gap is still big. The harmonization process of accounting has been studied in the world during the last decades, while the issue related to small and medium enterprises is not paid much attention and is quite new to a developing country like Vietnam; specifically, the study of the factors which affects the international accounting harmonization in Vietnamese small and medium enterprises. This paper studies the environmental factors that affects the harmonization process of accounting especially in the light of the views expressed by the accountants and the auditors. They are two opposite objects, the ones who make financial reports and the ones who check financial reports. The paper include introduction, literature review, hypothesis, data and research methods, results and discussions, conclusions and recommendations

\section{Literature Review}

Small and medium enterprises are increasingly strengthening their participation in international operations, at the same time they also need to attract domestic and foreign investments for development. Capital becomes a motivation for businesses' development, according to Erum, Hussain and Yousaf (2016); Choi and Yüce (2016). Khatun et.al (2016) indicate that the demand on transparent financial information which helps compare businesses becomes imperative and important. There are several studies on factors that affects the harmonization process of accounting. This process appears to narrow the gap between accounting systems and is able to lead to a common standard system which can be applied internationally. The application of international financial reporting standards for small and medium enterprises adduces for the harmonization process of accounting of businesses, according to $\mathrm{Ha}$ and Kang (2019). The application of international financial reporting standards will improve the quality of financial statements, according to Carlin; Finch and Tran (2014). Besides, businesses can also take hidden benefits when they apply supplement information disclosure policy, according to IFRS (Saemann, 1999; Nobes, 2012; Florou and Pope, 2012). The businesses can approach capital market more easily, offer higher product prices, and attract more experienced employees thanks to higher transparency than their competitors (Fox et.al 2013). The process of linking economies of the world, especially linking capital markets, requires standardization of accounting regulations. The international harmonization process of accounting brings overall benefits to all sides on the global scale. Particularly in the recent times, there have been many mergers and acquisitions in different countries, thus, it is necessary to have a common financial reporting standard system for businesses. The harmonization process of accounting in countries is influenced by the following theories.

\subsection{Theories about International Harmonization Process of Accounting}

\section{Theory of social interests}

This theory argues that regulations should be set up to meet society's demands for correcting inequalities and inefficiencies of market prices to protect common interests of the whole society. When it is applied to the field of accounting harmonization, this theory explains the role of International Accounting Standards Board in introducing appropriate institutions to ensure the organization's independence in developing international standards.

\section{Theory of group and personal interests}

Contrary to the theory of social interests, the theory of group interests argues that regulations are set up at the request of interest groups in the society based upon the principle of maximizing the interests of their members. For this theory, social organizations are not entirely objective. On the other hand, the theory of personal interests assumes that responsible people in any organization make rules based upon their personal interests. This theory is skeptical about the objectivity of regulatory bodies and argues that such bodies may be dominated by group or personal interests of those with regulatory functions. The rules will be purchased by the interest group that pays the highest price.

\section{Theory of useful information for making decisions}

This theory stems from the idea that financial statements provide too little information to the users, which makes it difficult for them to make decisions. The theory of useful information is the standard accounting theory used as the fundamental theory to formulate existing model of accounting theory for international financial reporting standards and many national accounting standards. This theory emphasizes that the basic task of financial statements is to provide useful and appropriate information to the users in making economic decisions. The theory of useful information also addresses the concept of cost-benefit balance, which is an important aspect to be considered in setting up the standards (Godfrey et al. 2003). When it is applied to the field of international accounting harmonization, this theory explains that the goal of international accounting harmonization process is to develop high quality standards to help investors and other entities to make their decisions in a more appropriate manner. Regulatory organizations also need to consider the costs (e.g., 
transformation) and benefits (more useful information in the international harmonization) of harmonization process.

\section{Theory of the diversity of national accounting practices}

Theories of the diversity of national accounting practices seeks to explain the differences in accounting practices among countries are because of unique characteristics of each country. This is a topic of great research interest and, over time, more and more factors have been identifies and analyzed. These factors have been categorized into four main groups: economic, legal, cultural and political.

\section{Agency theory}

This theory was initiated in the early 1970s and is based on the fact that the goals and interests of the principal and agent are not the same, leading to the implementation of actions that could be understood in different and certain ways. There is a conflict of objectives between two parties because of the existence of asymmetric information. Agency relationship is the cause of information asymmetry between the principal and the agent. The origin of this problem can be explained by the fact that the managers who directly manage a company's activities should understand its operations better than the investors and other external entities. Managers can influence the financial statements in such a way as to benefit themselves. The matters of agency relationship can be mitigated by using the strategies or actions that involves inspecting managers' activities, or providing them with incentives so that they take appropriate actions for the interests of the principal. This is necessary primarily because, in order to overcome and reduce supervision costs of the principal, managers must provide complete and accurate information to the parties that lack information. Financial statement is one of the important information channels that provide information to external parties to make decisions as well as enable them to assess the effectiveness of the management and use of resources by those that run the company. Therefore, the necessity of providing useful information to stakeholders is the result of the separation between ownership and governance.

\subsection{Accounting Harmonization Process for Small and Medium-Sized Enterprises}

Zeff (2007) discusses four main factors: (1) business culture and finance, (2) accounting culture, (3) audit culture and (4) legal culture, that may cause obstacles to the harmonization of practices among different countries. In addition to the existence of asymmetric information, researchers have the notion that tabulators and users of financial statements may have conflicting interests. The diversity of financial statement users increases the likelihood that the diversity of similar needs makes the comparison between users and tabulators irrelevant; however, all users support the consistency and completeness of disclosures. IASB also conducted many experiments with 116 SMEs in 20 different countries to identify the difficulties of SMEs in applying the draft IFRS for SMEs.

Schutte and Buys (2011) confirm that although there are not many related international activities, SMEs in the developing countries such as those in South Africa also have the needs for IFRS for SMEs. They carried out a survey on accountants of SMEs (157 respondents) to evaluate their response of IFRS for SMEs for their financial reporting in South Africa. Descriptive statistics reflected the fact that South African SMEs were less engaged in international activities, carried out less international transactions, had almost no international investment activities and mainly operated in domestic markets.

However, South African SMEs confirmed that there was still the need to apply IFRS for SMEs and the respondents from the survey said that IFRS for SMEs was suitable for them although its application would be complicated because of limited international activities of SMEs in South Africa. The initial costs for its application were particularly related to human resources and information technology. There are quite a number of studies indicating the suitability of IFRS for SMEs in many countries, such as Turkey, Hungary, Germany, and so on. They show that international financial reporting standards for SMEs will help these enterprises obtain easier access to capital markets. In the meanwhile, in countries with leading developed economies such as Germany, Brigitte and Haller (2009) conducted a survey on SMEs to assess the interests and needs of German SMEs related to IFRS for SMEs. According to results of statistical description, it was concluded that German SMEs were engaged in a lot of international business activities, mainly involving exports and imports, and most of them $(82 \%)$ required international financial reporting standards to have transparent and more competitive financial information.

However, there is an opinion such as that of Bohusova (2012) that these studies were mostly conducted in mediumsized enterprises rather than small-sized ones, so they were not representative. However, a number of studies such as by Feltham (2013) demonstrated that the quality of financial statements improved after the application of international financial reporting standards to SMEs. Factors that have an influence on the accounting harmonization process include business environment, legal environment and cultural environment. Factors of business environment include financial supply, inflation, and provision of laborspecific information. Factors of legal environment include legal system, role of the State and professional associations, and the influence of taxes Jeon (2018). Factors of cultural environment are typically those related to power distance, 
individualism, avoidance of unknown issues, long-term orientation, and masculinity. Three groups of economic, legal and cultural factors are not completely independent from each other, but they have close relationships and have interrelated impact on the international accounting harmonization process.

Upon considering the literature review, it was found that previous studies mainly focused on accounting harmonization process in developed countries rather than on the process in developing countries such as Vietnam. Countries with developing economies have many differences related to the institution, laws, and economic characteristics. IFRS does not provide any specific instruction and accountants may perform accounting work in a more flexible way. Such countries as Vietnam require more time and efforts than merely complying with the regulations, especially because human resources, and accounting systems in developed countries are not strong enough to meet the requirements for applying international accounting standards Nguyen and Richard (2011). IFRS is developed on the basis of the economies of developing countries, but this would be incomplete without the harmonization of accounting practices in developing countries such as Vietnam. Moreover, the subjects in this study are SMEs that account for a high proportion in Vietnamese business system; however, the accounting harmonization process among SMEs has received inadequate attention as they have simple, vague and inconsistent accounting systems and there is an inconsistency in the application of accounting standards by SMEs, etc. This author in this study has tried to address this gap.

\section{Hypothesis, Data and Research Methods}

\subsection{Hypothesis}

To compare the effects of environmental factors on the international harmonization process of accounting at small and medium enterprises based on points of view of accountants and auditors, we use the T-tests to evaluate the differences between the two sides. We have the first hypothesis to be verified:

H1: There is no difference in the evaluation of the effect of environmental factors on the harmonization process in the small and medium enterprises between the accountants and auditors.

The second hypothesis which needs to be verified involves costs and benefits related to the international harmonization process of accounting in small and medium enterprises indicated by the accountants and auditors:
H2: There is no difference in the evaluation of costs and benefits in the harmonization process in the small and medium enterprises between the accountants and auditors.

The third hypothesis involves the evaluation of the harmonization process in terms of whether it should or should not be applied for all small and medium businesses.

H3: There is no difference in the evaluation of the application of the harmonization process of accounting in all small and medium businesses.

\subsection{Research Data}

The author uses this research on the effect of environmental factors on the international harmonization process of accounting in small and medium enterprises and the applicability of international financial reporting standards through surveys. For this purpose, the author sends 150 survey papers to general accountants and chief accountants. All the general accountants and chief accountants in this survey have more than 5 years of experience in the field and are directly involved in making the financial reports. Besides, the research group also send 145 survey papers to auditors, assistant auditors at accounting firms. The auditors and assistant auditors all have more than 2 years of experience in the field. The author finally collects back just 100 survey papers from the accountants and 100 survey papers from the auditors

In the survey group of accountants, $65 \%$ are female and $35 \%$ are male; in the survey group of auditors, $59 \%$ are male. In the accountants group, the age group with the highest percentage are of 26-35 with 57\%, the ages of 36-45 occupy $28 \%$, and the ages of under 15 occupy $15 \%$. In the auditors' group, the age group below 26 is $34 \%$, the age group of $26-$ 35 dominates with $53 \%$, and the age group of over 35 is $13 \%$.

\subsection{Research Design}

The questions in the survey papers are evaluated based on a 5-point likert scale from 1 to 5 , in which 1 represents strongly disagreeing and 5 represents strongly agreeing. Through the T-Tests carried out on SPSS 200 software, the author wants to discover if there is any difference in the points of view of the accountants and auditors about the application of international financial reporting standards. This study is based on previous reseaches which assume that different roles offer different points of view. The first set of questions evaluate the accountants and auditors about the effect of environmental factors on the international harmonization process of accounting on small and medium enterprises. Environmental factors are inherited from the 
previous studies, including legal environment factor, cultural environment factor, and business environment factor.

The first question: According to you, does legal environment have any effect on the harmonization process of accounting in small and medium enterprises?

The second question: According to you, does cultural environment have any effect on the harmonization process of accounting in small and medium enterprises?

The third question: According to you, does business environment have any effect on the harmonization process of accounting in small and medium enterprises?

Then, the author finds about costs and benefits from the harmonization process of accounting in small and medium enterprises as well as the application of the harmonization process of accounting in all small and medium enterprises, according to the accountants' and auditors' point of view.

The fourth question: Do you suppose that benefits from the international harmonization process of accounting are superior to costs spent on this process?

The fifth question: Do you suppose that international financial reporting standards should be applied fully for all small and medium enterprises?

\section{Results and Discussion}

First of all, the author finds about the first hypothesis to consider if there is any difference between the accountants and auditos in evaluating the effect of environmental factors on the harmonization process of accounting in small and medium enterprises. To do this, the author compares the points of view of the accountants and auditors by considering the average value of data from the Independent Samples T-tests for the 100 accountants and 100 auditors. The likert scale is marked from 1 to 5 , in which 1 is the lowest level of evaluation. The evaluation is higher if it is closer to 5. The average point of evaluation of the effect of legal environment on the harmonization process of accounting from the accountants is 4.25 , from the auditors, it is just 2.92 . The verification result is shown in Table 1 .

In this case, the equality of the two variances in Levene's test is $0,325>0,05$, so we will use result of the two Equal variances assumed. To these tests, we should base on level of significances (sig) in the t-test for Equality of Means. The level of significance is $0,000<0,05$. Therefore, the accountants and auditors have a different evaluation of the effect of legal environment on the harmonization process of accounting. The accountants have a higher evaluation of the impact of legal environment on the harmonization process of accounting in small and medium enterprises than the auditors. Some studies show that accounting has the trend of recording and making financial reports suitable with tax regulations in order to reduce the difference between tax and accounting for easy explanation to authorities.

Table 1: Evaluation of the effect of legal environment on the harmonization process of accounting from the accountants and auditors

\begin{tabular}{|c|c|c|c|c|c|}
\hline \multicolumn{6}{|c|}{ Group Statistics } \\
\hline & Objects & $\mathbf{N}$ & Mean & Std. Deviation & Std. Error Mean \\
\hline \multirow{2}{*}{ Points } & Accountants & 100 & 4.25 & .642 & .064 \\
\hline & Auditors & 100 & 2.92 & .774 & .077 \\
\hline \multicolumn{6}{|c|}{ Independent Samples Test } \\
\hline & & & & \multicolumn{2}{|c|}{ Points } \\
\hline & & & & $\begin{array}{c}\text { Equal variances } \\
\text { assumed }\end{array}$ & $\begin{array}{l}\text { Equal variances } \\
\text { not assumed }\end{array}$ \\
\hline \multirow{2}{*}{$\begin{array}{l}\text { Levene's Test for } \\
\text { Equality of Variances }\end{array}$} & \multicolumn{3}{|l|}{$\mathrm{F}$} & .972 & \\
\hline & \multicolumn{3}{|l|}{ Sig. } & .325 & \\
\hline \multirow{7}{*}{$\begin{array}{l}\text { t-test for Equality of } \\
\text { Means }\end{array}$} & \multicolumn{3}{|l|}{$t$} & 13.226 & 13.226 \\
\hline & \multicolumn{3}{|l|}{ df } & 198 & 191.386 \\
\hline & \multicolumn{3}{|l|}{ Sig. (2-tailed) } & .000 & .000 \\
\hline & \multicolumn{3}{|l|}{ Mean Difference } & 1.330 & 1.330 \\
\hline & \multicolumn{3}{|c|}{ Std. Error Difference } & .101 & .101 \\
\hline & \multirow{2}{*}{\multicolumn{2}{|c|}{$\begin{array}{l}95 \% \text { Confidence Interval of the } \\
\text { Difference }\end{array}$}} & Lower & 1.132 & 1.132 \\
\hline & & & Upper & 1.528 & 1.528 \\
\hline
\end{tabular}


As far as the evaluation of the effect of cultural environment on the harmonization process of accounting from the accountants and auditors is concerned, the survey result shows differences between two objects. The average point from the accountants is 2.37 and from the auditors is 3.05. The level of significance is $0.00<0.05$, thus there is a clear difference between the opinions of auditors and accountants on this issue. The survey result is revealed in Table 2.

The average point of the accountants is just 2,69 and of the auditors is 3,68 . In this case, the equality of the two variances in Levene's test is $0,033<0,05$, so we will use result of the two Equal variances assumed. To these tests, we should base on level of significances ( $\mathrm{sig}$ ) in the t-test for Equality of Means. The level of significance is $0,000<0,05$. So, there are differences in the point of view of the accountants and auditors about the effect of business environment on the harmonization process of accounting. The auditors have higher evaluation than the accountants because with the role of financial report controllers, the auditors strongly need to pay attention to honesty and transparency of financial reports provided to investors.

So author can reject the H1. We can see the differences in the evaluation of the effect of environmental factors on the harmonization process of accounting in small and medium enterprises between accountants and auditors. The accountants attach much importance to legal environment which includes legal system, the role of the State and the career association as well as the effect of taxes. On the other hand, the auditors have a high appreciation for the role of business environment, including transparency of financial reports, on the international harmonization process of accounting in small and medium businesses.

Comparison of benefits and costs that enterprises are required to incur in applying international accounting harmonization process. Average point is 2.79 for accountants and 3.38 for auditors. Test results have significant level in the observation ( $\mathrm{sig})=0.000<0.05$. So, there is a difference in assessing benefits and costs in the application of international accounting harmonization process between accountants and auditors. As accountants are internal employees, they consider costs as the biggest barrier in international accounting harmonization process. This is especially true for SMEs which lack strong economic resources. Many researchers pointed that it is necessary to mitigate these difficulties, adapt to financial reporting needs of SMEs, balance between the costs and benefits of compliance, meet the needs to provide useful information for external information users in addition to tax authorities and corporate owners and managers, pay attention to the trend that SMEs may become listed enterprises, and narrow the gap between VAS applicable to SMEs and international financial reporting standards for SMEs. The result of evaluating is shown in Table 4.

Table 2: Evaluation of the effect of cultural environment on the harmonization process of accounting from the accountants and auditors

\begin{tabular}{|c|c|c|c|c|c|}
\hline \multicolumn{6}{|c|}{ Group Statistics } \\
\hline & Objects & $\mathbf{N}$ & Mean & Std. Deviation & Std. Error Mean \\
\hline \multirow{2}{*}{ Points } & Accountants & 100 & 2.37 & .774 & .077 \\
\hline & Auditors & 100 & 3.05 & .744 & .074 \\
\hline \multicolumn{6}{|c|}{ Independent Samples Test } \\
\hline & & & & \multicolumn{2}{|c|}{ Points } \\
\hline & & & & $\begin{array}{l}\text { Equal variances } \\
\text { assumed }\end{array}$ & $\begin{array}{l}\text { Equal variances } \\
\text { not assumed }\end{array}$ \\
\hline \multirow{2}{*}{$\begin{array}{l}\text { Levene's Test for Equality of } \\
\text { Variances }\end{array}$} & \multicolumn{3}{|l|}{$\mathrm{F}$} & 1.551 & \\
\hline & \multicolumn{3}{|l|}{ Sig. } & .214 & \\
\hline \multirow{7}{*}{ t-test for Equality of Means } & \multicolumn{3}{|l|}{$\mathrm{t}$} & -6.335 & -6.335 \\
\hline & \multicolumn{3}{|l|}{ df } & 198 & 197.684 \\
\hline & \multicolumn{3}{|l|}{ Sig. (2-tailed) } & .000 & .000 \\
\hline & \multicolumn{3}{|l|}{ Mean Difference } & -.680 & -.680 \\
\hline & \multicolumn{3}{|l|}{ Std. Error Difference } & .107 & .107 \\
\hline & \multirow{2}{*}{\multicolumn{2}{|c|}{$\begin{array}{l}95 \% \text { Confidence Interval of the } \\
\text { Difference }\end{array}$}} & Lower & -.892 & -.892 \\
\hline & & & Upper & -.468 & -.468 \\
\hline
\end{tabular}


Table 3: Evaluation of the effect of business environment on the harmonization process of accounting from the accountants and auditors

\begin{tabular}{|c|c|c|c|c|c|c|}
\hline \multicolumn{7}{|c|}{ Group Statistics } \\
\hline & Objects & $\mathbf{N}$ & Mean & Std. Deviation & \multicolumn{2}{|c|}{ Std. Error Mean } \\
\hline \multirow{2}{*}{ Points } & 1 & 100 & 2.69 & .800 & \multicolumn{2}{|c|}{.080} \\
\hline & 2 & 100 & 3.68 & .665 & \multicolumn{2}{|c|}{.066} \\
\hline \multicolumn{7}{|c|}{ Independent Samples Test } \\
\hline & & & & & \multicolumn{2}{|c|}{ Points } \\
\hline & & & & & $\begin{array}{c}\text { Equal } \\
\text { variances } \\
\text { assumed }\end{array}$ & $\begin{array}{c}\text { Equal } \\
\text { variances } \\
\text { not assumed }\end{array}$ \\
\hline \multirow{2}{*}{$\begin{array}{l}\text { Levene's Test for } \\
\text { Equality of Variances }\end{array}$} & \multicolumn{4}{|l|}{$\mathrm{F}$} & 4.625 & \\
\hline & \multicolumn{4}{|l|}{ Sig. } & .033 & \\
\hline \multirow{7}{*}{$\begin{array}{l}\text { t-test for Equality of } \\
\text { Means }\end{array}$} & \multicolumn{4}{|l|}{$\mathrm{t}$} & -9.516 & -9.516 \\
\hline & \multicolumn{4}{|l|}{ df } & 198 & 191.570 \\
\hline & \multicolumn{4}{|l|}{ Sig. (2-tailed) } & .000 & .000 \\
\hline & \multicolumn{4}{|l|}{ Mean Difference } & -.990 & -.990 \\
\hline & \multicolumn{4}{|c|}{ Std. Error Difference } & .104 & .104 \\
\hline & \multirow{2}{*}{\multicolumn{3}{|c|}{$95 \%$ Confidence Interval of the Difference }} & Lower & -1.195 & -1.195 \\
\hline & & & & Upper & -.785 & -.785 \\
\hline
\end{tabular}

Table 4: Comparison of benefits and costs that enterprises will have to spend in applying international accounting harmonization process

\begin{tabular}{|c|c|c|c|c|c|}
\hline \multicolumn{6}{|c|}{ Group Statistics: } \\
\hline & Subjects & $\mathbf{N}$ & Mean & Std. Deviation & Std. Error Mean \\
\hline \multirow{2}{*}{ Assessment value } & Accountant & 100 & 2.79 & .624 & .062 \\
\hline & Auditor & 100 & 3.38 & .616 & .062 \\
\hline \multicolumn{6}{|c|}{ Independent Samples Test } \\
\hline & & & & \multicolumn{2}{|c|}{ Mark } \\
\hline & & & & $\begin{array}{l}\text { Equal variances } \\
\text { assumed }\end{array}$ & $\begin{array}{c}\text { Equal variances } \\
\text { not assumed }\end{array}$ \\
\hline \multirow{2}{*}{$\begin{array}{l}\text { Levene's Test for Equality of } \\
\text { Variances }\end{array}$} & \multicolumn{3}{|l|}{$\mathrm{F}$} & 1,028 & \\
\hline & \multicolumn{3}{|l|}{ Sig. } & .312 & \\
\hline \multirow{7}{*}{ t-test for Equality of Means } & \multicolumn{3}{|l|}{$\mathrm{t}$} & $-6,727$ & $-6,727$ \\
\hline & \multicolumn{3}{|l|}{ df } & 198 & 197,964 \\
\hline & \multicolumn{3}{|l|}{ Sig. (2-tailed) } & .000 & .000 \\
\hline & \multicolumn{3}{|l|}{ Mean Difference } & -.590 & -.590 \\
\hline & \multicolumn{3}{|l|}{ Std. Error Difference } & .088 & .088 \\
\hline & \multirow{2}{*}{\multicolumn{2}{|c|}{$\begin{array}{l}\text { 95\% Confidence Interval of the } \\
\text { Difference }\end{array}$}} & Lower & -.763 & -.763 \\
\hline & & & Upper & -.417 & -.417 \\
\hline
\end{tabular}


Table 5: Assessment of application of international accounting harmonization process for all small and medium-sized enterprises.

\begin{tabular}{|c|c|c|c|c|c|}
\hline \multicolumn{6}{|c|}{ Group Statistics: } \\
\hline & Subjects & $\mathbf{N}$ & Mean & Std. Deviation & Std. Error Mean \\
\hline \multirow[t]{2}{*}{ Assessment value } & Accountant & 100 & 2.45 & .520 & .052 \\
\hline & Auditor & 100 & 2.52 & .522 & .052 \\
\hline \multicolumn{6}{|c|}{ Independent Samples Test } \\
\hline & & & & \multicolumn{2}{|c|}{ Diemdanhgia } \\
\hline & & & & $\begin{array}{l}\text { Equal variances } \\
\text { assumed }\end{array}$ & $\begin{array}{l}\text { Equal variances } \\
\text { not assumed }\end{array}$ \\
\hline \multirow{2}{*}{$\begin{array}{l}\text { Levene's Test for Equality } \\
\text { of Variances }\end{array}$} & \multicolumn{3}{|l|}{$\mathrm{F}$} & .060 & \\
\hline & \multicolumn{3}{|l|}{ Sig. } & .807 & \\
\hline \multirow{7}{*}{$\begin{array}{l}\text { t-test for Equality of } \\
\text { Means }\end{array}$} & \multicolumn{3}{|l|}{$\mathrm{t}$} & -.950 & -.950 \\
\hline & \multicolumn{3}{|l|}{ df } & 198 & 197.997 \\
\hline & \multicolumn{3}{|l|}{ Sig. (2-tailed) } & .343 & .343 \\
\hline & \multicolumn{3}{|l|}{ Mean Difference } & -.070 & -.070 \\
\hline & \multicolumn{3}{|l|}{ Std. Error Difference } & .074 & .074 \\
\hline & \multirow{2}{*}{\multicolumn{2}{|c|}{$\begin{array}{l}\text { 95\% Confidence Interval of the } \\
\text { Difference }\end{array}$}} & Lower & -.215 & -.215 \\
\hline & & & Upper & .075 & .075 \\
\hline
\end{tabular}

We can either reject the $\mathrm{H} 2$ as there are differences between the accountants and auditors in the evaluation of costs and benefits in relation to the harmonization process of accounting in small and medium businesses.

Application of international accounting harmonization process for all small and medium-sized enterprises. This option is poorly assessed by both accountants and auditors with mean values of 2.45 and 2.52 , respectively. The significance level is $0.343>0.05$. So, there is no difference in opinions of accountants and auditors regarding this matter. For Micro-sized enterprises, it is difficult to ask them to meet high-level international standards (See Table 5). We cannot reject the $\mathrm{H} 3$ because there is no variance in the evaluation of the application of the harmonization process of acocunting for all small and medium businesses.

\section{Conclusions and Recommendations}

Through survey assessment of the factors that have an influence on accounting harmonization process for SMEs, it can be seen that there are legal environment factors. On the other hand, for auditors, business environment factors are highly important, i.e. the transparency and integrity of financial statements. Accountants hold the point of view that benefits of applying international financial reporting standards are not higher than the costs, on the contrary, auditors hold the view that benefits are higher than the costs.

Internationalaccounting harmonizationis anindispensable trend, but how it should be approached is a question that must be answered on the basis of different economic, political, social, and cultural contexts as well as different origins. Survey results show that accountant in enterprises are not really ready for full application of international financial reporting standards for SMEs. Vietnam should follow the approach of modified application of international financial reporting standards to adapt to its corporate environment. We would recommend that Vietnamese Accounting Standards Council and the Ministry of Finance should rely on the International Financial Reporting Standards for SMEs, practical conditions of Vietnam, extensive surveys, and opinions of experts and stakeholders to develop the system of highly feasible accounting standards for application in practice at enterprises. In addition, Vietnamese system of international financial reporting standards should always be updated in accordance with the international changes. 
Through results of the survey on opinions of accountants and auditors, the application of accounting standards should not be applied to all of SMEs. According to regulations, micro-sized enterprises should not apply international financial reporting standards for SMEs as there is not enough potential and is not necessary to do so. In addition, through the interviews with the author, some of the standards prescribed in IFRS for SMEs cannot be applied to existing SMEs as these are the standards that do not offer suitable conditions for SMEs. Some regulations, such as government funding, employee benefits, stock-based payments, and financial reporting in a hyperinflationary economy, as well as the group of basic standards, mostly occur in SMEs, and they should be fully applied first. These are the standards that regulate the concept of small and medium-sized enterprises, accounting principles, regulations on financial statements and a number of standards related to basic elements of financial statements, such as tangible and intangible fixed assets, inventory, revenue and other income, borrowing costs.

Within its competence, the Government should promulgate appropriate financial mechanisms or options for dealing with differences among accounting standards, financial mechanisms and tax policies. The State should agree with enterprises that disclose information to users such as investors, creditors, employees, suppliers, etc. so that they comply with accounting standards. Managers need to pay attention to financial statements to ensure compliance with the accounting standards. Managers and accountants also need to improve the awareness that information in financial statements is not intended for tax authorities, but is intended for business owners and stakeholders for decision-making purposes.

\section{References}

Brigitte, E., \& Haller, A. (2009). Does Size Influence the Suitability of the IFRS for Small and Medium-Sized Entities?: Empirical Evidence from Germany. Accounting in Europe, 6(2), 195-220. https://doi.org/10.1080/17449480903115779

Bohusova, H. (2012). In what ways are countries which have already adopted IFRS for SMEs different. Acta Universitatis Agriculturae et Silviculturae Mendelianae Brunensis, 60(2), 37-44. DOI: 10.11118/actaun201260020037

Carlin, M. T., Finch, N., \& Tran, D. M. (2014). IFRS Compliance in the Year of the Pig: Hong Kong Impairment Testing. Journal of Economics \& Development. 16(1), 23-39. DOI: $10.33301 / 2014.16 .01 .02$

Choi, Y., \& Yüce, A. (2016). Foreign Direct Investment Projects of Korean Companies. Journal of Asian Finance, Economics and Business, 3(1), 5-14. https://doi.org/10.13106/jafeb.2016. vol3.no1.5

Danie, S., \& Buys, P.W. (2011). A comparative evaluation of South African SME financial statements against the IFRS requirements. Journal of Accounting and Taxation, 3(1), 8-22.
Ehoff, C., \& Fischer, D. (2013). Why The SEC Is Delaying Adoption Of International Financial Reporting Standards. International Business \& Economics Research Journal, 12(2), 223-227.

Erum, N., Hussain, S., \& Yousaf, A. (2016). Foreign Direct Investment and Economic Growth in SAARC Countries. Journal of Asian Finance, Economics and Business, 3(4), 57-66. https://doi.org/10.13106/jafeb.2016.vol3.no4.57

Feltham, D. (2013). The Adoption of International Accounting Standards for Small- and Medium-Sized Entities. Doctoral dissertation, Walden University, Minesote, United States.

Florou, A., \& Pope, F.P. (2012). Mandatory IFRS adoption and institutional investment decisions. The Accounting Review, 87(6), 1993-2025. DOI: 10.2139/ssrn.1362564

Fox, A., Helliar, C., Veneziani, M., \& Hannah, G. (2013). The Costs and Benefits of IFRS Implementation in the UK and Italy. Journal of Applied Accounting Research, 14(1), 86-101. https://doi.org/10.1108/09675421311282568

Godfrey, J., Mather, P., \& Ramsay, A. (2003). Earnings and Impression Management in Financial Reports: The Case of CEO Changes, A Journal of Accounting, Finance and Business Studies, 39(1), 95-123. https://doi.org/10.1111/14676281.00122

Ha, M., \& Kang, M. (2019). IFRS reconciliation adjustment and subsequent meet or beat target earnings. Journal of Asian Finance, Economics and Business, 6(1), 33-45. http://doi. org/10.13106/jafeb.2019.vol6.no1.33

Jeon, J. H. (2018). The Impact of Asian Economic Policy Uncertainty: Evidence from Korean Housing Market. Journal of Asian Finance, Economics and Business, 5(2), 43-51. https://doi.org/10.13106/jafeb.2018.vol5.no2.43

Khatun, N., Naima, J., Karim, Z., \& Alam, L. (2016). Importance of Annual Report to the Shareholders: Empirical Evidence from Bangladesh. Journal of Asian Finance, Economics and Business, 3(4), 67-77. https://doi.org/0.13106/jafeb.2016. vol3.no3.67.

Nguyen, P. C., \& Richard, J. (2011). Economic Transition and Accounting System Reform in Vietnam. European Accounting Review, 20(4), 693-725. https://doi.org/10.1080/09638180.201 1.623858

Nobes, C. (2012). The survival of international differences under IFRS: Towards a research agenda. Accounting and Business Research, 36(3), 233-245. https://doi.org/10.1080/00014788.2 006.9730023

Saemann, G. (1999). An Examination of Comment Letters Filed in the U.S. Financial Accounting Standard: Setting Process by Institutional Interest Groups. Abacus, 35(1), 1-28. https://doi. org/10.1111/1467-6281.00032

Schutte, D. P., \& Buys, P. (2011). A critical analysis of the contents of the IFRS for SMEs: A South African perspective. South African Journal of Economic and Management Sciences, 14(2), 188-209.

Zeff, S. A. (2007). Some obstacles to global financial reporting comparability and convergence at a high level of quality. The British Accounting Review, 39(2007), 290-302. 